\title{
PROBLEMS AND POTENTIALITIES FOR THE STUDY OF INTERNAL POPULATION MOBILITY IN NINETEENTH-CENTURY ENGLAND
}

\author{
Richard Lawton \\ University of Liverpool, Liverpool, England \\ and \\ Colin G. Pooley \\ University of Lancaster, Lancaster, England
}

Résumé - La mobilité démographique était importante en Angleterre au dix-neuvième siècle, causant un décroissant de population rurale, un accroisement urbain rapide, et aidant le développement des communes bien différenciées en dedans des cités victoriennes. Les sources d'information qu'on peut utiliser pour l'étude de la mobilité démographique du dix-neuviéme siècle sont, cependant, restreintes. L'étude présente établit les problèmes et les possibilités de l'usage de ces sources mettant en lumière les aspects choisis par l'entremise des exemples de migration vers et en dedans de Liverpool. On a identifié trois échelles d'analyse et on a suggéré une classification des principaux types de migration. Finalement, on a insisté sur les liaisons entre chaque type de migration et sur l'importance du mouvement individuel.

Abstract - Population mobility was important in nineteenth-century England causing rural depopulation, rapid urban growth, and aiding the development of well-differentiated areas within Victorian cities. The sources which may be used to study nineteenth-century population mobility are, however, limited. This paper assesses the problems and potentialities of utilizing these sources illustrating selected aspects through examples of migration to and within mid-Victorian Liverpool. Three scales of analysis are identified and a classifaction of major migration types is suggested. Finally, links between each migration type are emphazised and the importance of individual movement is stressed.

\section{Key Words - sources and methods; population mobility; nineteenth-century} England

\section{Introduction}

In population dynamics the larger the unit of analysis, the greater the proportion of change ascribable to natural trends: in the closed world system the migration component is nil. But, at regional and, especially, sub-regional levels, migration often dominates; the smaller the unit of study, the larger the relative importance of population movement. Moreover, at times of rapid environmental, social, or economic change migration is likely to increase, both absolutely and relatively, dominating short-term trends and, through its effects on population structure, significantly shaping future trends.

Nineteenth-century England experienced marked regional contrasts in population growth. Most rural areas reached a population peak in mid-century and thereafter lost heavily except, by the late nineteeth century, in areas near the larger towns (Cairncross, 1953; Lawton, 1967). Most rural migrants travelled only a short distance, cumulatively creating ripples of migration setting towards the towns and industrial areas, which accounted for much of the regional redistribution of population in the mid-nineteenth century (Redford, 1926). By the later nineteenth century, migration between cities and industrial areas - often occupationally selective - was important in both quantitative and qualitative terms (Cairncross, 1953; Weber, 1899; Lawton and Pooley, 1976). 
While differential net migration has been studied in some detail (Welton, 1911; Cairncross, 1953, Lawton, 1968) and has been related to fluctuations in relative regional prosperity and economic growth in nineteenth-century England (Thomas, 1954), much less work has been done on the characteristics of migration streams and their demographic and socio-economic impact on both sending and receiving areas. This paper outlines sources of information for a study of population mobility in nineteenth-century England, discusses problems of their use, and from studies of migration to and within mid-Victorian Liverpool, illustrates the processes involved.

\section{Migration in Nineteenth-Century England: Sources and Problems}

The evidence for regional studies of migration in nineteenth-century England is limited and mainly indirect. Continuous population registers recording changes of address have been kept in Britain only in the national Register of 1939-1952 (Newton and Jeffrey, 1951). Compulsory civil registration of births, marriages, and deaths, which enables individuals to be identified at various points in their lives, began in England and Wales in 1837. From these, relatively accurate net migration figures can be calculated by comparing natural with total population changes over common periods from 1841, though more sketchy estimates may be derived from parish registers prior to 1837. A census question on birthplace, first asked in 1841, permits studies of lifetime migration both from census tabulations and, within certain constraints of confidentiality, from details of individuals listed in the unpublished enumerators' books. Finally, recent British censuses have gathered information on residential mobility over one year prior to the enumeration in 1961 and over one and five years in the 1966 and 1971 censuses. Of these four types of migration data, only the first provides direct evidence of mobility and only the second and third (net migration and birthplaces) exist for nineteenth-century England.

Before the Civil Registration Act of 1837, estimates of births and deaths can be made from parish baptismal and burial registers (Wrigley, 1966). Despite problems of incompleteness, due to non-registration or omission of dissenters, they may be used to estimate natural and migrational components of population change, as in the Parish Register Abstracts of the 1801-1841 censuses.

Figures of net migration based on civil registration are more accurate, despite under-registration of births until the Act of 1874 (Glass, 1938 and 1973). Censuses from 1851 until 1911 included tabulations of natural change and net migration for the 620 registration districts of England and Wales. Similar figures may be derived for the 2,200 or so registration sub-districts in the country using the Annual Reports of the Registrar General from 1838. Hence, a relatively detailed picture may be built up of the components of population change at a regional and sub-regional level (Lawton, 1968; Lawton and Pooley, 1976).

More direct information on the origins of those enumerated comes from a census question on birthplace. The 1841 census recorded those born in the county in which they were enumerated and those born in the rest of England and Wales, in Scotland, in Ireland, in the colonies, or overseas. From 1851 the census enumerators recorded the parish and county of birth for English and Welsh-born, together with those born, respectively, in Scotland, Ireland, Islands in the British Seas, at sea, and abroad (distinguishing between British and foreign born). ${ }^{1}$ This information was tabulated in varying detail in published censuses (Table 1 ).

The original census schedules also included details of age, sex, marital status, relationship to head of household, and occupation for each enumerated individual. 
TABLE 1. INFORMATION ON BIRTHPLACES IN CENSUS REPORTS, 1841-1911

\begin{tabular}{|c|c|c|c|c|}
\hline $\begin{array}{l}\text { Cen- } \\
\text { sus }\end{array}$ & Volume & Enumerated in & Born in & Classified by \\
\hline 1841 & $\begin{array}{l}\text { Enumeration Abstract } \\
(7843)\end{array}$ & $\begin{array}{l}\text { (i) Parish or town- } \\
\text { ship } \\
\text { (ii) Hundred and Shire }\end{array}$ & $\begin{array}{l}\text { (i) County where born } \\
\text { and el sewhere } \\
\text { (ii) Other counties of } \\
\text { England and } \\
\text { Wales; Scotland, } \\
\text { Ireland, Colonies, } \\
\text { foreign-born. }\end{array}$ & $\begin{array}{l}- \\
-\end{array}$ \\
\hline $\begin{array}{l}1851 \\
\text { and } \\
7861\end{array}$ & $\begin{array}{l}\text { Vol. II } \\
\text { 'Ages, civil condition } \\
\text { and Birthplaces' } \\
\text { (1853 and } 1863)\end{array}$ & $\begin{array}{l}\text { (i) Registration } \\
\text { District; } \\
\text { Boroughs, cities, } \\
\text { Principal or } \\
\text { large towns. } \\
\text { (ii) Registration } \\
\text { counties (derived } \\
\text { from (i)) }\end{array}$ & $\begin{array}{l}\text { (i) Geographical } \\
\text { (civil) counties } \\
\text { of England and } \\
\text { Wales. } \\
\text { (ii) Scotland: Ireland; } \\
\text { Islands in the } \\
\text { British Seas; at } \\
\text { sea; abroad } \\
\text { (British and } \\
\text { foreign-born). }\end{array}$ & $\begin{array}{l}\text { (i) } M \text { and } F(1861 \\
\text { on } 7 y) \text {. } \\
\text { (ii) Under and over } \\
20 \text { years of age. }\end{array}$ \\
\hline 1871 & $\begin{array}{l}\text { Vol. III } \\
\text { 'Ages, civil condition } \\
\text { and Birthplaces' } \\
(1873)\end{array}$ & $\begin{array}{l}\text { Geographical County; } \\
\text { principal or large } \\
\text { towns }\end{array}$ & As for 1851 and 1867 & As for 1861 \\
\hline $\begin{array}{l}1881 \\
\text { and } \\
189.1\end{array}$ & $\begin{array}{l}\text { Vol. III } \\
\text { 'Ages, condition as } \\
\text { to marriage, occupa- } \\
\text { tions, birthplaces, } \\
\text { infirmities } \\
\text { (1883 and } 1893)\end{array}$ & $\begin{array}{l}\text { Geographical County: } \\
\text { Urban Sanitary } \\
\text { Districts over } \\
50,000 \text { population. }\end{array}$ & As Above & $M$ and $F$ \\
\hline 1901 & $\begin{array}{l}\text { County volumes, } \\
\text { Tables } 36 \text { and } 37 \\
\text { (various dates) }\end{array}$ & $\begin{array}{l}\text { (i) Geographical } \\
\text { County, County } \\
\text { and Metropolitan } \\
\text { Boroughs } \\
\text { (ii) Urban areas over } \\
50,000\end{array}$ & $\begin{array}{l}\text { As above, together } \\
\text { with country of birth } \\
\text { of foreign-born }\end{array}$ & $\begin{array}{l}\text { (i) } M \text { and } F \\
\text { (ii) Civil condition, } \\
\text { age and } \\
\text { occupation of } \\
\text { foreigners by } \\
\text { country of birth } \\
\text { (London, } \\
\text { Lancashire and } \\
\text { Yorkshire on } 1 y \text { ). }\end{array}$ \\
\hline 1911 & $\begin{array}{l}\text { Vol. IX } \\
\text { 'Birthplaces' } \\
\text { (1913) }\end{array}$ & $\begin{array}{l}\text { Administrative County } \\
\text { (including Urban } \\
\text { Districts); } \\
\text { County and Municipal } \\
\text { Boroughs; } \\
\text { Urban Districts over } \\
50,000\end{array}$ & $\begin{array}{l}\text { Administrative County } \\
\text { (including Urban } \\
\text { Districts); } \\
\text { County and Municipal } \\
\text { Boroughs; } \\
\text { Urban Districts over } \\
50,000\end{array}$ & $\begin{array}{l}\text { (i) } M \text { and } F \\
\text { (ii) for selected } \\
\text { counties and } \\
\text { towns by age } \\
\text { groups, under 20; } \\
20-24 ; 25-34 ; \\
35-44 ; 45-54 ; \\
55-64 ; 65 \text { and } \\
\text { over. } \\
\text { (iii) for } 9 \text { selected } \\
\text { counties, } \\
\text { marital status. } \\
\text { (iv) Occupations of } \\
\text { foreign-born by } \\
\text { country of birth } \\
\text { (for London, } \\
\text { Lancshire, and } \\
\text { Yorkshire onty). }\end{array}$ \\
\hline
\end{tabular}


Enumerators transcribed this information into enumerators' books - now in the Public Record Office - from which the tabulations of the census reports of 1841-1901 were derived (Armstrong, 1966 and 1978). ${ }^{2}$ Although access to census enumerators' books is restricted under a 100 -year confidentiality rule to those for $1841-1871,{ }^{3}$ they have been used in detailed studies of a number of towns and regions (Lawton, 1955 and 1959; Pooley, 1977; Anderson, 1971; Armstrong, 1974; Hall, 1974; Shaw, 1977), while others have linked census data with, for example, civil registration records, electoral rolls or directories in studies of intra-urban mobility (Pritchard, 1976; Taylor, 1971; Dennis, 1977).

There are several problems in using published census birthplace tabulations in studies of mobility. First, birthplaces reflect "lifetime migration," not the time or place of people's previous movements. They cannot yield longitudinal studies of migration experience such as can be reconstructed from population registers. Secondly, migration differentials cannot be effectively assessed since published birthplace data have no cross-tabulations other than inconsistent disaggregation by age and sex (Table 1). Thirdly, neither the areal basis of enumeration nor of birthplace is consistent from census to census. Population origins and migration flows are generally classified by "geographical or civil county," the administrative area for which birthplaces are most commonly recorded in nineteenth-century censuses. The unit of enumeration varies: registration districts and counties, used in 1851 and 1861, overlap civil counties and create problems of estimating actual lifetime migration between adjacent counties (Darby, 1943, Lawton, 1958; Baines, 1972). Civil counties were the basis of both enumeration and origin in 1871-1901 but in 1911 the basis was the administrative county, excluding county and municipal boroughs, which were tabulated separately, together with certain large urban districts. Thus, while in 1911 a matrix of some $300 \times 300$ units can be used, this is difficult to compare with the previous $53 \times 53$ county matrix (Baines, 1978). Only in 1911, in special tabulations for four countries and 11 towns, were lifetime migrants cross-tabulated by age-groups (Table 1). Such inconsistencies make difficult the estimation of changes in the pattern and level of migration over time.

\section{Population Movement at a Macro-Scale}

Pioneer studies by E.G. Ravenstein (1876 and 1885) identified a number of characteristics of internal migration in England and Wales in 1871 and 1881 that he designated as 'Laws' (Grigg, 1977), and which subsequent studies have largely validated (Lee, 1969). He recognized the contribution of migration to population trends in areas of gain (counties of absorption) and of loss (counties of dispersion), the nature of migration streams (dominated by short-distance movement, declining away from centres of attraction or dispersal), the stepwise nature of most movements, the tendency for every migrational movement to produce a counter-flow, and for females to be more migratory than males over short distances.

Subsequent studies of internal migration in nineteenth-century England have been largely based on the administrative areas in census tabulations of birthplaces; these include several studies of counties or regions (Darby, 1943; Smith, 1951; Lawton, 1958). A few, though, have used complementary data, such as Redford's pioneer study of labour migration based on Poor Law Reports (Redford, 1926). However, to show intercensal patterns of movement adjustments must be made that take account not only of changes in the numbers of lifetime migrants enumerated in an area (given in birthplace tables), but also of deaths among previous migrants, losses by re-migration, and natives who left their county but returned again during the intercensal period. While it is impossible to 
compensate for all these variables, better estimates of both intercensal migration change and of migration flows between units of enumeration in the various censuses can be made.

The greatest problem is adjusting for deaths among lifetime migrants since these are influenced by the age and sex structure and, to an extent, the socio-economic structure of migrants, neither of which can be derived from published census tables. Since most migrant populations have a more youthful structure than the population as a whole, general mortality rates will overestimate the adjustment to be made. In an early attempt to calculate intercensal migration, H.A. Shannon (1935) studied decadal changes in migration to and from London, 1851-91, by calculating deaths among previous lifetime migrants to give an estimate of surviving migrants, and by estimating new migrants minus re-migrants. Shannon applied current mortality rates for age-groups $35-45$ centered on 1861-71, and adjusted the age-specific mortality calculation for surrounding decades for each specific decadal migration group. Similar calculations were attempted for out-migrants, but without adjusting for emigration, for which no estimates could be made.

Similarly, D.E. Baines (1972 and 1978), adjusted for deaths among lifetime migrants between areas, using the probable age distribution of the migrant stream, while other estimates of lifetime migration adjusted for migrant mortality include those of Hill (1925) and Lawton and Pooley (1976).

The most detailed analysis of this kind, by Friedlander and Roshier (1966), uses a survivorship ration to calculate intercensal changes in migration in England and Wales, 1851-1951. Using the age-structure of lifetime migrants for selected counties in the 1911 census, they estimated net volume of migration in particular streams, the ages of past migrants at the time of migration, and their subsequent mortality experience. Assuming a constant migrant age-structure, they applied the age survivorship formula to all areas, tests of their calculations suggesting that the migration estimates from 1851 to 1911 produced results within a few per cent of the actual age structure of migrants given in the 1911 census. From the survivorship formula they calculated gross and net migration streams for non-adjacent counties and summarized the changing pattern of inter-county migration, 1851-1951.

\section{Population Movement at a Meso-Scale}

Published censuses and Registrar General's reports provide a background to, but tell us little of the process of nineteenth-century migration. Fortunately, the census enumerators' books partially fill this gap. In particular, they allow the identification of differentials in population movement with respect to occupational and socio-economic status, age, sex, and family life-cycle stage, while a tentative interpretation of the pattern of stepwise movement in population migration may be attempted.

There are, however, a number of important problems in such studies apart from the general constraints of census accuracy (Tillott, 1972) and the severe limitations imposed by a reliance on birthplace information (see above; see also United Nations, 1970; Kosinski, 1975).

First, the enumerators' books are unwieldly and time-consuming to use. Information on individuals - though useful for many purposes - must be aggregated into appropriate units for subsequent analysis. The mass of data tends to restrict the researcher to studies of specific localities and of gross migration into particular destinations, for the identification of out-migrants is almost impossible. Such migration studies give only a partial picture of the migration system and are best suited to analyses 
Richard Lawton and Colin G. Pooley

of the impact of in-migration on particular places, the significance of which for the development of migration theory is obviously dependent upon the representativeness of the example.

Secondly; although population movement is a dynamic process, censuses record it in static decennial cross-sections. A comprehensive picture of migration characteristics and of the impact of migration demand, ideally, six distinct pieces of information: the population characteristics of the source regions; the characteristics of migrants prior to migration; the characteristics of a migrant on arrival at a particular destination; the destination's social and demographic structure prior to the arrival of a particular wave of migrants; its characteristics after the migrants' arrival; and, finally, changes in migrant characteristics after a period of residence in a destination. Generally, however, each of these elements must remain conjectural. There is no direct information on time of migtation or characteristics prior to movement and only by linking individuals through decennial censuses can we attempt to measure changes in the migrant population of a town and patterns of migrant assimilation.

Thirdly, lifetime migration (as recorded in census enumerators' books) is a poor surrogate for direct information on actual population movement. Ravenstein (1885), Cairncross (1949) and Redford (1926), among others, have stressed the stepwise nature of much nineteenth-century population movement, dominant flows being up the urban hierarchy as in many developing nations today (Safa and Dutoit, 1975a and 1975b). The census provides no direct information on life-cycle stage at the time of migration or on pattern of movement, thus severely restricting studies of the nineteenth-century migration process. The nearest one can get to measuring stepwise moves is through an analysis of the birthplaces of children born to migrant parents. Though providing only a small and biased sample of married migrants to whom children were born in an intermediate destination, such analyses are suggestive of the migration process (Lawton and Pooley, 1976:82-83; Bryant, 1971).

Fourthly, small samples generally affect studies of nineteenth-century migration: even within a large total sample population, subgroups of migrants from particular source regions may be very small. Together with inherent inaccuracies in nineteenth-century census data, this severely limits statistical analysis.

Lastly, though the census provides information on the individual movers, unlike present-day researchers we cannot question the respondents, making it difficult or impossible to establish precise motivations for movement. Thus, although decision-making models (Wolpert, 1965; Brown and Moore, 1970) are as applicable to historical as to present-day studies, they are more conjectural in character and based upon the limited individual cases that are documented.

Despite these limitations, meso-scale studies based on census enumerators' books, provide important insights into the process of migration in the nineteenth century. A neglected aspect, the link between migration and socio-economic and occupational status, is selected for discussion in this paper. It was hypothesized, first, that socio-economic group (measured by a simple ranking of occupation) would differentiate between migration streams; and, secondly, that longer-distance migrants - especially those coming from or passing through other urban areas - would be of a higher socio-economic group than short-distance rural-urban migrants. A higher socio-economic group was thought to reflect greater ability, initiative, and incentive to move over long distances and, possibly, a greater awareness of potential opportunities.

A ten per cent sample of household heads resident in Liverpool Borough in 1871 was divided into seven socio-economic groups and 22 birthplace regions (Table 2). Differences between the Bocio-economic distribution of each migrant group, tested by 


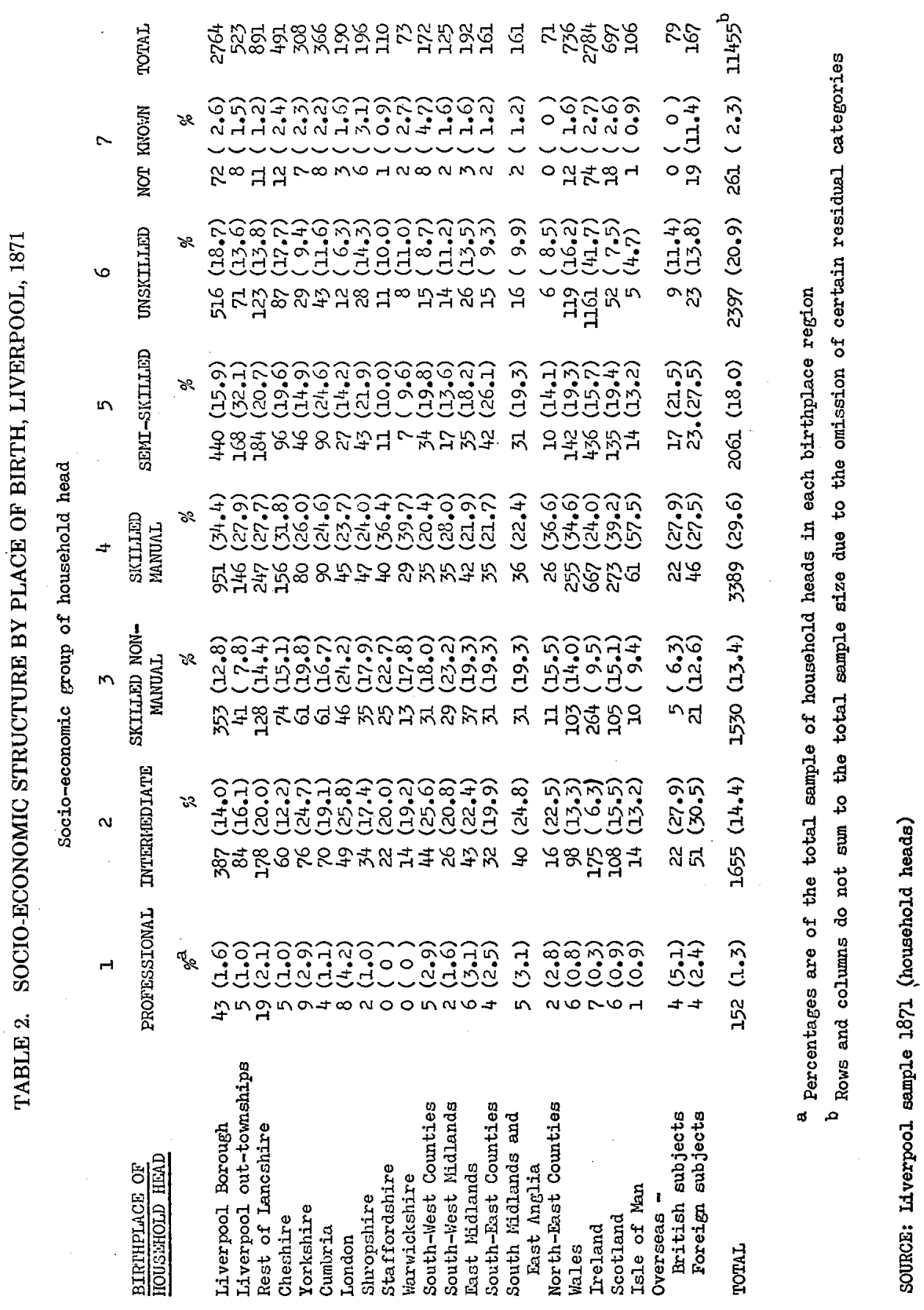


Chi-Square, allow the identification of a series of regional groupings with similar socio-economic characteristics.

The three most distinct groups - the Irish, the Scots, and the Welsh - formed the largest body of migrants in mid-Victorian Liverpool and had the greatest impact upon the social and demographic structure of the city (Pooley, 1977). Each group differed in its socio-economic characteristics: the Irish were dominated by semi-skilled and unskilled workers, as demonstrated in other studies (Lees, 1969; Richardson, 1968; Lobban, 1971), whereas the Welsh and the Scots were over-represented in the skilled manual and skilled non-manual classes. Migrants from other areas of England were less clearly associated with any one socio-economic group, but all except the Irish were under-represented among the unskilled, and migrants other than the Irish, regardless of the distance or direction of movement, tended to have a larger proportion in higher socio-economic groups than non-migrants.

The relatively large source regions used in this study precluded precise distance measures, but shorter-distance migrant streams - especially those from mainly rural areas such as Cumbria, Cheshire, Lancashire, Shropshire, and North Wales - had higher proportions of lower-status workers than those from farther afield (e.g., from eastern and southern England); the latter were relatively dominated by people in professional, managerial, and intermediate classes.

The relationship between socio-economic group and the nature of the source regions seems to have been more important than that between socio-economic group and distance alone. Assuming that many, if not most, long-distance migrants had moved to Liverpool via other large urban areas, they would have had a chance to gain urban skills and experience, perhaps explaining their higher status in Liverpool in 1871. This hypothesis is also supported by the fact that short- and medium-distance migrants from other urban areas were also mainly of high social status, or were in occupations suited to the job market of nineteenth-century Liverpool.

Much longer-distance migration was stimulated by particular job opportunities on Merseyside and, by the third quarter of the nineteenth century, rural-urban migration had been to a considerable extent replaced by large-scale interchange of migrants with other urbanized regions such as the West Midlands (Lawton and Pooley, 1976:79-81), a feature symptomatic of a general tendency in Britain (Welton, 1911; Thomas, 1930). Migrants from Staffordshire and Warwickshire were heavily represented in intermediate and skilled occupations, especially metal manufacturing and dealing both of which required previous industrial skills or sufficient capital to set up business in another town. Specific occupational links between source and destination are apparent among migrants from Staffordshire to Liverpool who were concentrated in machine and iron manufacture, whilst Warwickshire-born clustered in such specialist jobs as watch-making and copper and tin manufacture. Many such men travelled from one urban area to another in occupationally related, medium or long-distance migration, taking up trades followed in their home area (Briggs, 1952; Timmins, 1866; Vance, 1967). Such occupation-selective migrations were important in nineteenth-century England and deserve more careful analysis than they have hitherto received.

\section{Population Movement at a Micro-Scale}

Another neglected aspect of population movement in nineteenth-century England is intra-urban residential mobility, on which only Pritchard (1976) and Dennis (1977) have published detailed studies. Rather more studies have been undertaken in North America including those of Katz (1976) and Knights (1971). Such relative neglect is partly due to 
the variety of possible approaches, partly to the difficulties of data. Nevertheless, to investigate the nineteenth-century migration system without reference to intra-urban movement is to neglect an important complement to rural-urban and urban-rural flows. Much nineteenth-century urban growth was the result of in-migration (Law, 1967; Lawton, 1967), but once within a town the population was not static: residential mobility helped to develop distinctive social areas in nineteenth-century British cities (Lawton and Pooley, 1975b; Pritchard, 1976).

There are two broad approaches to the study of residential mobility: first, the impact of mobility on the social areas of the town, measuring persistence or turnover within a given area by comparing population listings at two dates (Knights, 1971); secondly, by a study of individual residential mobility linking frequency and distance moved within the city to occupation, socio-economic group, age, life-cycle stage, housing tenure, and the like. The degree of accuracy with which such studies can be made depends mainly on the periodicity of the population listings that are compared. These range from census enumerators' books, which miss many intermediate moves (Dennis, 1977), through electoral rolls (Pritchard, 1976), annual or biennial city directories (Lawton and Pooley, 1976), and rate books (Holmes, 1973), to personal diaries (Lawton and Pooley, 1975a), which may be the nearest we can get in historical research in England to the construction of a personal migration history (Hagerstrand, 1969).

All such sources present problems. The census provides most information on an individual, but its ten-year periodicity is a severe disadvantage: studies have shown that only 40 to 50 per cent of a population persist within an entire city for a decade, let alone at a single address (Knights, 1971; Katz, 1976). Electoral rolls and directories are biased in their coverage - often omitting the mass of the working class population - while rate books are often inconsistent in their coverage and accuracy. Diaries containing information on mobility are very rare and may be atypical. The study of intra-urban mobility in Liverpool reported in this paper is based on the linkage of decennial censuses and biennial directories through the decades 1851-61 and 1871-81. Using a total sample of 2,446 households, census enumerators' books provided a check on the completeness of the directories and, though working-class areas are under-represented, the sample streets chosen for study were almost completely covered in the directories.

Apart from sample bias, there are further problems in the study of intra-urban mobility. Nominal record linkage between sources is much easier where a large amount of information is available to identify the individual being traced (Wrigley, 1973). Census books provide a wealth of information, but directories contain only surname, initial or forename, and occupation: with common names and occupations, possible links must often be discarded because of uncertainty over identification. There are, therefore, considerable losses from the original sample that are difficult to apportion between the possible causes which include mortality, out-migration, and omission from the later source.

Lastly, the problem of sample representativeness must be considered. Time spent in data extraction and record linkage often means that, in a large town, only small sample areas can be studied. These must be carefully and objectively selected if results are used to interpret residential mobility over the whole city. While rates of population turnover were high in mid-Victorian Liverpool (only 17.9 per cent of households persisted ten years at the same address) there was considerable stability of persistence rates over the two decades studied: in this paper the decades 1851-61 and 1871-81 are analyzed together to give a larger sample size.

The variables controlling intra-urban mobility in mid-Victorian Liverpool - age, socio-economic status, housing tenure, and life cycle-stage - were similar to those 
Richard Lawton and Colin G. Pooley
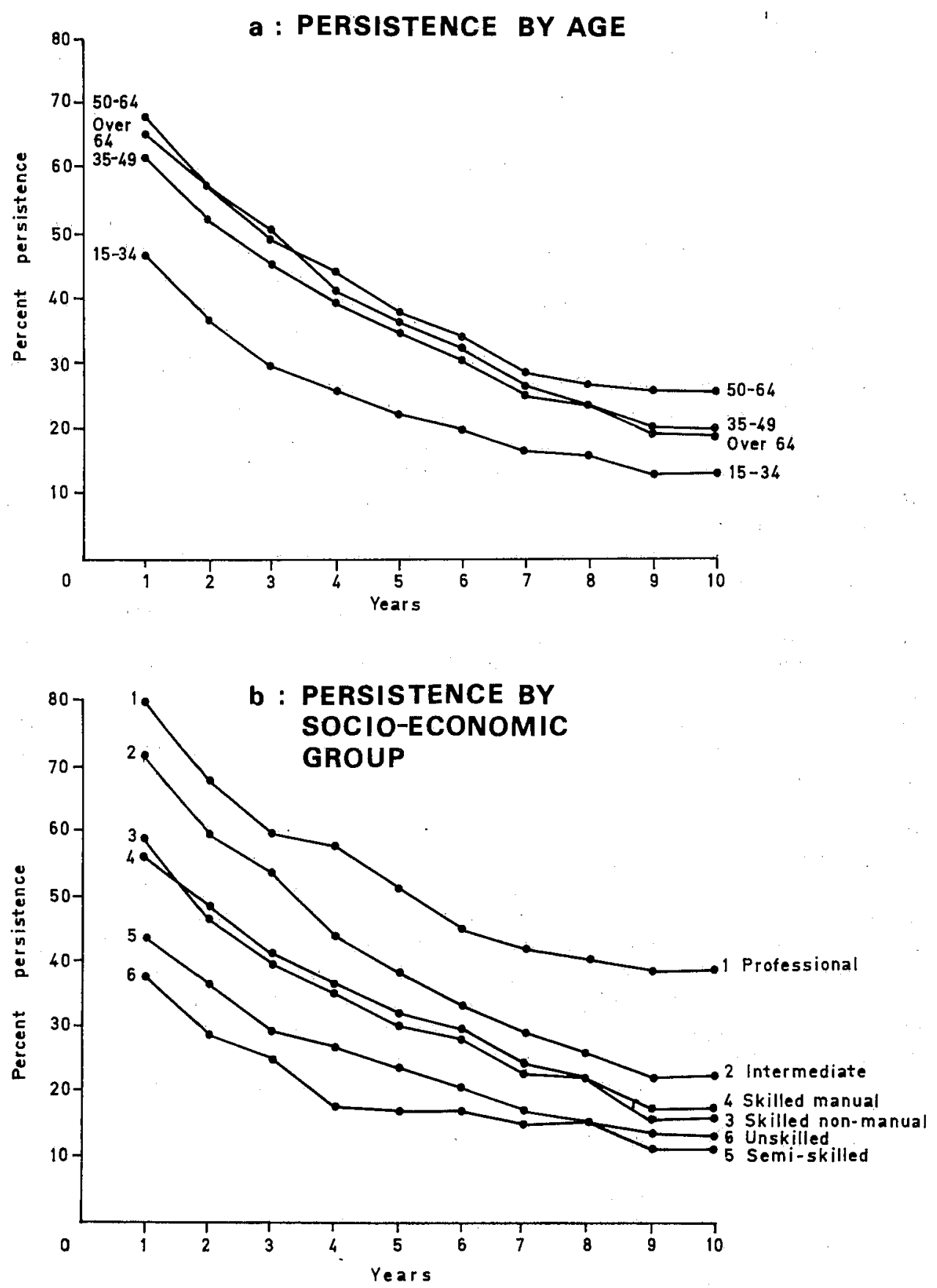

FIGURE 1. RESIDENTIAL PERSISTENCE IN SELECTED AREAS OF LIVERPOOL, 1851-61 AND 1871-81, (a) BY AGE OF HOUSEHOLD HEAD; (b) BY SOCIO-ECONOMIC GROUP. 
demonstrated in present-day studies (Brown and Moore, 1970; Simmons, 1968; Rossi, 1955): similar conclusions for Huddersfield (Yorkshire) have been drawn by Dennis (1977). Mobility was higher among young adults (aged 15 to 34) in the family-building stage of the life-cycle, while older families had a more stable residential pattern; persistence rates increased progressively with age until reduced in the over-64 age group by higher mortality (Fig. 1a).

Rate books are not available for mid-Victorian Livepool, but since owner-occupancy was rare in Victorian England and essentially confined to the upper classes (Chapman, 1971; Tarn, 1971; Gauldie, 1974), socio-economic group (based on occupation) may be used as a surrogate for housing tenure, assuming that only higher socio-economic groups would contain a substantial number of home owners. Though lower socio-economic groups are under-represented in the sample, there is a clear pattern of high rates of persistence in the professional, managerial, and intermediate groups, among whom home ownership was a disincentive to movement and greater financial independence permitted longer journeys to work. In contrast, manual workers, who had lower incomes, a less secure, often casual job, and generally rented their homes, could move easily in response to a change in job, a change in family circumstances, or a financial crisis or personal whim (Fig. 1b). Most Victorian cities had an abundance of terrace housing at similar rents which facilitated such ease of movement (Chapman, 1971; Gauldie, 1974).

Short-distance movement dominated mobility patterns in mid-Victorian Liverpool with 70.3 per cent of removals under one mile and 33.2 per cent less than 0.25 miles: only the professional and intermediate classes were over-presented in longer-distance moves. The upper classes thus moved less frequently but over longer distances, reflecting both their greater financial resources and knowledge of alternative locations in the city, while the spatial pattern of their movement was limited by the distribution of higher status residential areas in the city.

From the linkage of population listings much can be learned about the pattern and process of residential mobility in the Victorian city, which, with due allowances for the different housing market and restricted urban public transport system of the time, bears remarkable resemblance to the results of studies of present-day residential mobility. However, such studies still beg the question of why an individual makes a particular move. In historical research, only oral history or personal diaries can begin to fill this gap (Burnett, 1974; Thompson, 1973).

Two diaries compiled in the Liverpool of the 1880s, and reported elsewhere (Lawton and Pooley, 1975a) amplify the outlines of population mobility presented above, but their interpretation is difficult. Their scarcity makes it difficult to assess typicality, and it is dangerous to generalize on the basis of a relatively few diaries. Such records are important, however, if we are to move beyond bare statistical analyses of population mobility into the study of decision-making processes underlying nineteenth-century mobility.

\section{Conclusions}

In this review it has not been possible to present a comprehensive picture of the methods and range of analyses undertaken in the study of internal migration in nineteenth-century England. There is, however, vast potential for further research at local, regional, and national levels despite the imperfections of the data. Population movement must be analyzed at a number of scales, different methodologies and different sources often being used at each scale of analysis. Existing studies reveal a number of distinctive elements in the nineteenth-century migration system which are shown in 
Richard Lawton and Colin G. Pooley

TABLE 3. CLASSIFICATION OF NINETEENTH-CENTURY MIGRATION

\begin{tabular}{|c|c|c|}
\hline Type of Move & Iong Distance & Short Distance \\
\hline Rural-Rural & Temporary harvest migration. & $\begin{array}{l}\text { Local inter-village movement } \\
\text { including marriage } \\
\text { migration. }\end{array}$ \\
\hline Rural-Urban & $\begin{array}{l}\text { Usually a series of 'stepwise' } \\
\text { moves up the urban } \\
\text { hierarchy. }\end{array}$ & $\begin{array}{l}\text { Nost conmon during early } \\
\text { phase of urban growth - } \\
\text { short distance movement } \\
\text { to nearest tow. }\end{array}$ \\
\hline Urban-Urban & $\begin{array}{l}\text { Increasingly common between } \\
\text { large cities after about } \\
1860 \text {. }\end{array}$ & $\begin{array}{l}\text { Hovement up urban hierarchy } \\
\text { from smali tow to nearby } \\
\text { city. }\end{array}$ \\
\hline Urban-Rural & - & $\begin{array}{l}\text { Moverent of high-status } \\
\text { households to rural sub- } \\
\text { urbs. }\end{array}$ \\
\hline Intra-Urban & - & $\begin{array}{l}\text { Frequent short distance } \\
\text { moves mostly in same area } \\
\text { of city. }\end{array}$ \\
\hline
\end{tabular}

Table 3. These range from temporary harvest migration, particularly from Ireland (Johnson, 1967), to the short-distance intra-urban mobility discussed above.

There has been a tendency to investigate each type of migration separately, for instance rarely linking long-distance inter-urban movements with intra-urban mobility; yet individual migration histories are likely to encompass a range of migration experience (Figure 2). An individual may begin life in a rural area, move once in that area, and then, through a series of longer-distance moves up the urban hierarchy, reach a large city. Short-distance moves within the same town may be followed by a longer-distance move to another city and then by removal to a semi-rural suburb. Thus to fully understand the operation of the nineteenth-century migration system we need to analyze not only the spatial and structural features of each particular component, but also to combine information from a wide range of local and national sources on the mobility experience of individuals, from which an integrated view of the processes operating across the whole spectrum of population movement in nineteenth-century Britain may be developed. 


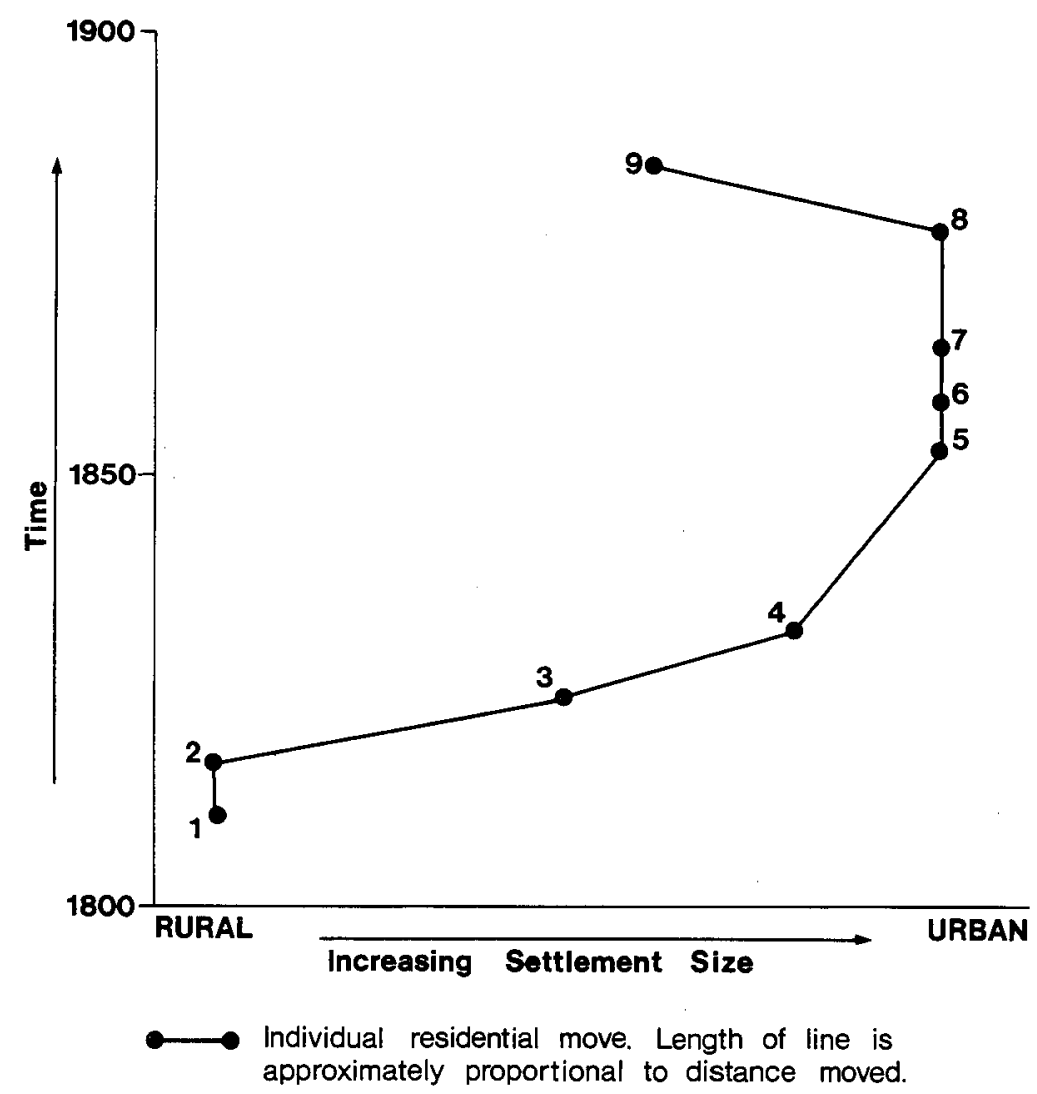

FIGURE 2. THEORETICAL PATTERN OF NINETEENTH-CENTURY INDIVIDUAL LIFE-TIME MIGRATION EXPERIENCE.

\section{Footnotes}

1. The census of Scotland gives birthplace divisions by county within Scotland and, outside of Scotland, those born in England and Wales; Ireland, Islands in the British Sea; at sea and overseas (British and foreign-born).

2. The 1911 census used punch cards as the basis of analysis of the individual schedules.

3. In Scotland a 70-year rule operates.

4. Based on research arising out of the S.S.R.C.-sponsored Social Geography of Nineteenth-Century Merseyside Project, directed by Professor Richard Lawton. Fuller details of the project and research findings can be found in Lawton and Pooley (1976).

\section{References}

Anderson, M. 1971. Family Structure in Nineteenth-Century Lancashire. Cambridge: The University Press.

Armstrong, W.A. 1966. Social Structure from the early Census Returns. In E.A. Wrigley (ed.), An Introduction to English Historical Demography. London: Weidenfeld and Nicolson.

. 1974. Stability and Change in an English County Town. A Social Study of York 1801-51. Cambridge: The University Press.

1978. The Census Enumerators' Books: a Commentary. In R. Lawton (ed.), The Census and Social Structure: an interpretative guide to 19 th century censuses. London: Cass. 
Baines, D.E. 1972. The use of published census data in migration studies. In E.A. Wrigley (ed.), Nineteenth-century society. Cambridge: The University Press.

1978. Birthplace statistics and the analysis of internal migration. In R. Lawton (ed.), The census and social structure. London: Cass.

Briggs, A. 1952. History of Birmingham. Vol. II. Oxford: The University Press.

Brown, L.A., and E.G. Moore. 1970. The intra-urban migration process: a perspective. Geografiska Annaler Series B 52:1-13.

Bryant, D. 1971. Demographic trends in south Devon in the mid-nineteenth century. In K.J. Gregory and W.L.D. Ravenhill (eds.), Exeter essays in geography. Exeter: The University Press.

Burnett, J. 1974. Useful Toil. London: Allen Lane.

Cairncross, A.K. 1949. Internal migration in Victorian England. The Manchester School 17:67-87. 1953. Home and foreign investment, 1870-1913. Cambridge: The University Press.

Chapman, S.D. (ed.) 1971. The history of working-class housing. Newton Abbott: David and Charles.

Darby, H.C. 1943. The movement of population to and from Cambridgeshire between 1851 and 1861 . Geographical Journal 101:118-25.

Dennis, R.J. 1977. Intercensal mobility in a Victorian city. Transactions of the Institute of British Geographers New Series 2:349-63.

Friedlander, D., and R.J. Roshier. 1966. A study of internal migration in England and Wales: Part I, Geographical Patterns of internal migration, 1851-1951. Population Studies 19:239-79.

Gauldie, E. 1974. Cruel habitations: a history of working-class housing 1780-1918. London: Allen and Unwin.

Glass, D.V. 1938. Changes in fertility in England and Wales. In L. Hogben, Political Arithmetic. London: Allen and Unwin. 1973. Numbering the people. Farnborough: Saxon House.

Grigg, D.B. 1977. E.G. Ravenstein and the laws of migration. Journal of Historical Geography 3:41-54.

Hagerstrand, T. 1969. On the definition of migration. Scandinavian Population Studies 1:63-72.

Hall, R. 1974. Occupation and population structure in part of the Derbyshire Peak District in the mid-nineteenth century. East Midland Geographer 6:66-78.

Hill, A.B. 1925. Internal migration and its effects upon the death rates with special reference to the county of Essex. Medical Research Council.

Holmes, R.S. 1973. Ownership and migration from a study of ratebooks. Area 5:242-51.

Johnson, J.H. 1967. Harvest migration from nineteenth-century Ireland. Transactions of the Institute of British Geographers 41:97-112.

Katz, M.B. 1976. The people of Hamilton, Canada West: family and class in a mid-nineteenth century city. Harvard: The University Press.

Knights, P.R. 1971. The plain people of Boston, 1830-60. New York: Oxford University Press.

Kosinski, L.A. 1975. Data and measures in migration research. In L.A. Kosinski and R.M. Prothero (eds.), People on the move. London: Methuen.

Law, C.M. 1967. The growth of urban populations in England and Wales 1801-1911. Transactions of the Institute of British Geographers 41:125-43.

Lawton, R. 1955. The population of Liverpool in the mid-nineteenth century. Transactions of the Historic Society of Lancashire and Cheshire 107:89-120.

1958. Population movements in the West Midlands, 1841-1861. Geography 43:164-77.

1959. Irish migration to England and Wales in the mid-nineteenth century. Irish Geography 4:35-54.

1967. Rural depopulation in nineteenth-century Britain. In R.W. Steel and R. Lawton (eds.), Liverpool essays in geography: a Jubilee collection. London: Longmans.

1968. Population changes in England and Wales in the later nineteenth century: an analysis of trends by registration districts. Transactions of the Institute of British Geographers 44:55-74. 
Lawton, R. and C.G. Pooley. 1975a. Individual appraisals of nineteenth-century Liverpool. Working paper 3. Social geography of nineteenth-century Merseyside project. University of Liverpool: Department of Geography.

1975b. The urban dimensions of nineteenth-century Liverpool. Working paper 4. Social geography of nineteenth-century Merseyside project. University of Liverpool: Department of Geography.

1976. The social geography of Merseyside in the nineteenth century. Final report to the S.S.R.C. University of Liverpool: Department of Geography.

Lee, E.S. 1969. A theory of migration. In J.A. Jackson (ed.), Migration. Cambridge: The University Press.

Lees, L.H. 1969. Patterns of lower-class life: Irish slum communities in nineteenth-century London. In S. Thernstrom and R. Sennett (eds.), Nineteenth-century cities: Essays in the new urban history. New Haven: Yale University Press.

Lobban, R.D. 1971. The Irish community in Greenock in the nineteenth century. Irish Geography 6:270-81.

Newton, M.P. and J.R. Jeffrey. 1951. Internal migration: studies in medical and population subjects 5. London: H.M.S.O.

Pooley, C.G. 1977. The residential segregation of migrant communities in mid-Victorian Liverpool. Transactions of the Institute of British Geographers New Series 2:364-82.

Prichard, R.M. 1976. Housing and the spatial structure of the city. Cambridge: The University Press.

Ravenstein, E.G. 1876. Census of the British Isles, 1871; Birthplaces and migration. Geographical Magazine 3:173-7; 201-6; 229-33.

1885. The Laws of migration. Journal of the Royal Statistical Society 48:167-235.

Redford, A. 1926. Labour migration in England 1800-1850. Manchester: The University Press.

Richardson, C. 1968. Irish settlement in mid-nineteenth-century Bradford. Yorkshire Bulletin of Economic and Social Research 20:40-57.

Rossi, P.H. 1955. Why families move. Glencoe, Ill: The Free Press.

Safa, H.I., and B.M. DuToit. (eds.) 1975a. Migration and Urbanisation. The Hague: Mouton. .1975b. Migration and Development. The Hague: Mouton.

Shannon, H.A. 1935. Migration and the growth of London 1841-1891. Economic History Review 5:78-86.

Shaw, M. 1977. The ecology of social change: Wolverhampton. 1851-71. Transactions of the Institute of British Geographers New Series 2:332-48.

Simmons, J.W. 1968. Changing residence in the city. Geographical Review 58:622-51.

Smith, C.T. 1951. The movement of population in England and Wales in 1851 and 1861. Geographical Journal 107:200-210.

Tarn, J.N. 1971. Working-class housing in nineteenth-century Britain. London: Lund Humphries.

Taylor, P.J. 1971. Distance transformation and distance decay functions. Geographical Analysis $3: 221-38$.

Thomas, B. 1930. The Migration of labour into the Glamorganshire Coalfield. Economica 10:275-94.

Thomas, B. 1954. Migration and economic growth: a study of Great Britain and the Atlantic Economy. Cambridge: The University Press.

Tillott, P.M. 1972. Sources of inaccuracy in the 1851 and 1861 censuses. In E.A. Wrigley (ed.), Nineteenth-century society. Essays in the use of quantitative methods for the study of social data. Cambridge: The University Press.

Timmins, S. (ed.). 1866. The resources, products and industrial history of Birmingham and the Midland hardware district. London: Hardwicke.

Thompson, P. 1973. Voices from within. In H.J. Dyos and M. Wolff (eds.), The Victorian City. London: Routledge and Kegan Paul. 
Richard Lawton and Colin G. Pooley

United Nations. 1970. Methods of measuring internal migration. Department of Economic and Social Affairs. Population Studies 47: New York.

Vance, J.E. 1967. Housing the worker: determinative and contingent ties in nineteenth-century Birmingham. Economic Geography 43:95-127:

Weber, A.F. 1899. The growth of cities in the nineteenth century: a study in statistics. New York: Macmillan.

Welton, T.A. 1911. England's recent progress. London: Chapman and Hall.

Wolpert, J. 1965. Behavioural aspects of the decision to migrate. Papers and proceedings of the Regional Science Association 15:159-69.

Wrigley, E.A. (ed.). 1966. An introduction to English historical demography. London: Weidenfeld and Nicolson.

1972. Nineteenth-century society. Essays in the use of quantitative methods for the study of social data. Cambridge: The University Press.

1973. Identifying people in the past. London: Edward Arnold.

Received December, 1977; revised August, 1978. 